\title{
MENTAL HEALTH OF SPECIALISTS AND EMOTIONAL STATE OF INFANTS WHO ARE IN INSTITUTIONAL CARE
}

\author{
Adolfas Juodraitis \\ Liuda Radzevičienè \\ Diana Strakšienė \\ Šiauliai University, Lithuania
}

\begin{abstract}
An article tries to reveal presumptive relationships of mental health of special educators and emotional stage of infants. In this context we discuss mental health of teachers (reasons and signs of it) and emotional reactions of infants. In specific educational environment mental health of teachers is an important factor of successful pedagogical process and infant development, as well. Pedagogue in Infant home acts as a creator of the stimulating environment for child's space of development. The analysis of expression of emotional status of infants let us draw a conclusion, that optimal psychological health of caregivers impresses emotional condition of deprived infants. The boys are more influenced by psychological condition of caregivers then girls.
\end{abstract}

Key words: infant home, early age children, emotional reactions, and psychological health of caregivers.

\section{Introduction}

Development of the early age children in the institutional environment does not go in the conformity with law of the nature.

The success of education in early infancy depends on the child's ability to react to the environmental changes to express his/her emotions and on it in adequate way. Creation of cognitive environment and managing pedagogical processes depends on the professional - personal characteristics of the teachers, who at the same time are: mothers, teachers, "fathers" and grannies. In the scientific researches of special education there is no enough studies concerning psychological health of educators working in the state care institutions with the early age children. It's evident that during the last years a significant attention in national science was paid to the analysis of pedagogical competences, values, and level of professional abilities (Ruškus, 2000; Juodaitytè, Rūdytè, 2009; Aramavičiūtè, 2006; Bitinas, 2004; Vasiliauskas, 2005; Ruškus, Gerulaitis, 010).

Any positive educational activity might be realized on the optimal emotional stage. Emotional status of child at this age reflects psychological health and even at this age psychological health is attackable most of all. Perforce close relationships between infant and special educator must be set because of "basic biological" duties to represent family, with it's complex meaningful. This situation forms specific type of social interaction, that's why psychological health of educator is one of the most significant indicators, that effects valuable child development. Problems of emotional and social development of infants, 
who are brought up in care institutions were discussed by researchers (Žukauskienè, 2012; Kaffemanas, 2000). Anyway, the revealed facts were never connected with the psychological health of educators.

Scientific studies in this area are important, because they can help us to understand educational specify better, that take place in the care institutions. Anyway, the background of any education is mentally stable and healthy people. Health - is a state of physical, mental, and social well - being which changes over time (Seligman, Walker, Rosenhan, 2001). It is true, that mental health partly depends on people social well - being. So unstable socioeconomic situation decrease the potency of mental health. This idea of our research reviews a new point of scientific significance. Mental health is a harmonious multi-complex of complicated biological and social factors. In working definition it's close to the definition of social health as a dimension of individual well - being distinct from both physical and mental health (Berns,2008). In many cases, the health status may be a function of non - heath factors external to the individual, such as the environment, the community and significant social groups. Social well - being measures focus on constructs such as role - related coping, family health and social participants. So according this presumption, mental health of teachers working in cares institutions for the early age children, might be defined as an object of social health.

Research object: mental health of special educators and its reflection on infant's emotional reactions.

The goals of research: 1) to determinate the main characteristics of psychical health of caregivers (special pedagogues), 2) to evaluate infant's, who have lost care of their parents, emotional particularities, 3) to find out some correlations with emotional stage of infants and psychological health of caregivers. That's why we organized triple - piece research (estimation of the main characteristics of psychical health of specialists, evaluation of emotional development of infants, and setting result correlation).

Hypothesis of the research. Mental health of special educators has presumptive relationships with infant's emotional status.

Methods of the research. We used closed form questionnaires (LEMON Learning Material On Nursing, 2008) to set mental health of infant home teachers, observation of infants' emotional reactions, and SPSS package for setting variables correlation, methods of descriptive statistics. During 1 month of observation we fixed different emotional reactions of infants. Spontaneous, joy, curiosity, impatience, and lack of attention, hyperactivity, irritability, apathy, and indifference were categorized and assessed. Emotional reactions and states were selected after longitudinal observations of infant's emotional status. At the same time the predominant psychological status of the same day of caregiver was fixed. 
Quotas of the research were 60 caregivers of 4 Infant Homes of Lithuania, and 120 infants from 6 to 24 month of age.

\section{Characteristics of Infant home teachers and infants that took place in the research}

Teachers that took part in this research differ according their age, educational level, professional experience and lengths of service. During the last years the educational level of caregivers became more professional, and it is conditioned by the requirements of market economy. The heads of institutions prefer to take person whose professional qualification is higher.

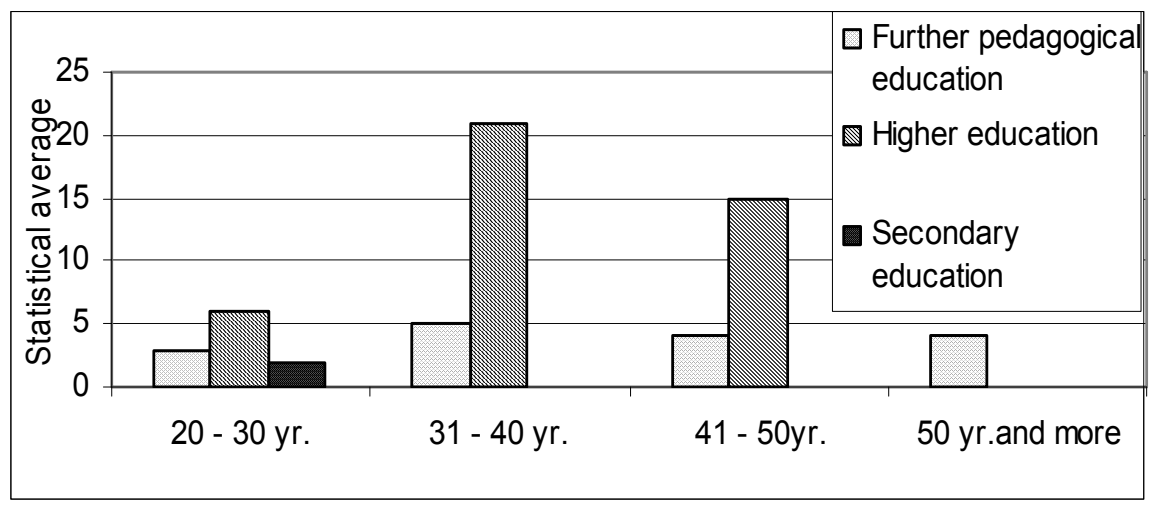

Figure 1 Age and education of infant home teachers

Most of all teachers are $31-40$ old women with higher pedagogical education (Fig.1).

Significant indication of mental health is a marital status of women, that in any case it might acts as a positive or negative factor.

Most of the teachers live in marital status and it might be indicated as a positive factor for their mental health, anyway, the level of marital life quality we do not assessed. It's obvious that comparatively high level of divorced women has some psychological problems that influenced their mental health (Fig.2).

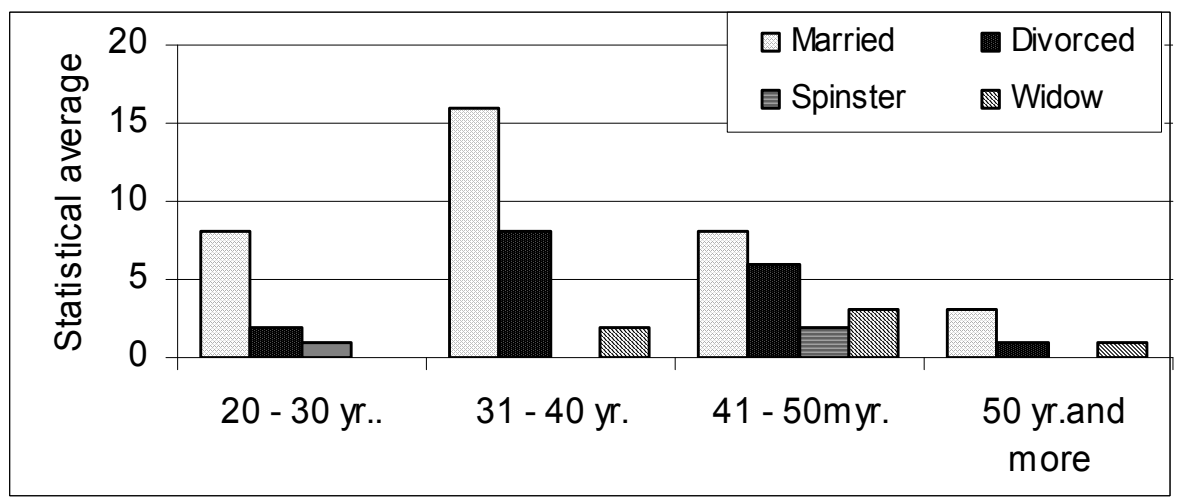

Figure 2 The marriage bonds of infant home teachers 
We analyzed cases of 120 infants who were placed to Infant Home, because their parents couldn't take care about them. We characterized them according age, gender and age, when they were placed to Infant home.

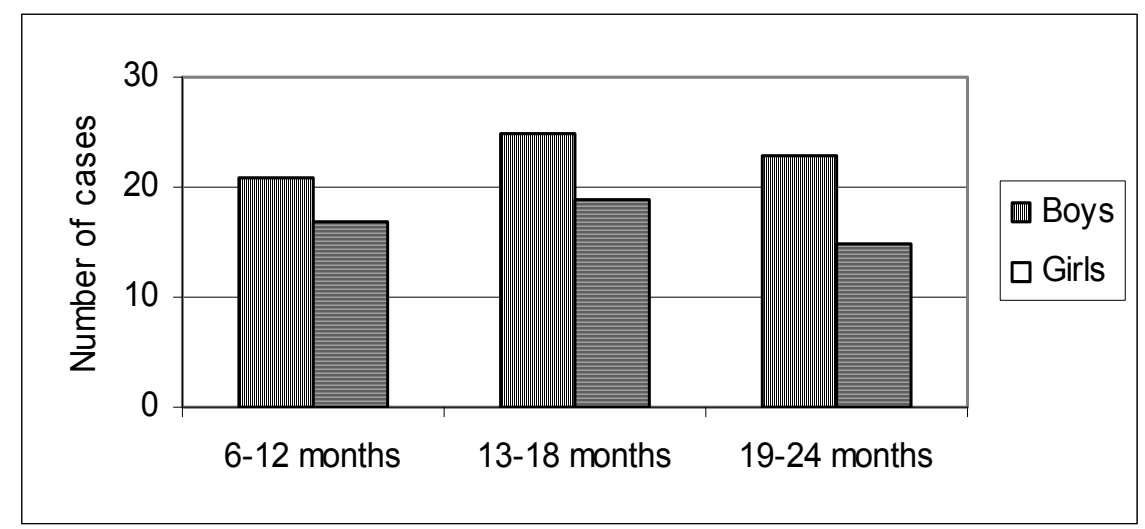

Figure 3 Infants according there age and gender

In all age groups we set up prevailing gender of boys (Fig.3). It's regular, because during the last years the number of boys was higher then number of girls. In the research quota there were no significant differences in number of genders.

The age then child is placed to infant home is significant according to the state of infant's natural socio-psychological growth: forming of the type of the attachment, sense of security, dyadic relationships and other. That's why mental health of caregiver (special educator) has primary dependence on the infant's development quality.

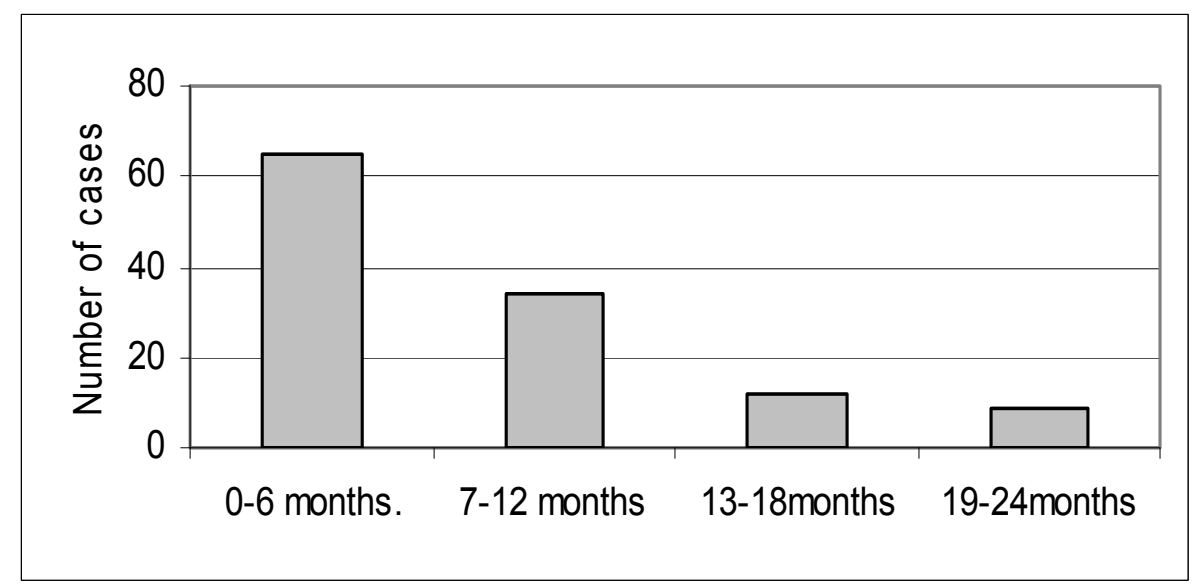

Figure 4 Age of Infants at the moment of their placement to Infant Home

Most of the infants were placed from 0 to 6 months of age (Fig.4). It is precarious period, because all mentioned characteristics forms at this period of infant's age. 


\section{Analysis of presumptive relationships of teacher's mental health and emotional stage of infants}

Analyzing results of teacher's mental health we clarified the emotional tiredness, long lasting depressive and stress situations. In $12(20 \%)$ cases we could talk about normal emotional stage of caregivers only. In the rest cases we found out: $15(25 \%)$ nurses are exhausted emotionally and statistically significance of stressful situation was found out in $33(55 \%)$ cases. The main reasons, that were mentioned, why they feel unhappy, were:

1. Hard economical situation in the family,

2. Health problems.

3. Unemployment of one of the members of caregivers' family.

4. Problems in relations with the members of caregivers' family.

5. Psychological problems in the institution.

6. Others.

It's common, that caregivers mentioned several reasons of their depressive situation. The prevailing emotions, mentioned in questionnaire were: tiredness, unhappiness, having a lot of troubles, worthless, loss of illusions and confidence in people, despair. Most part of the caregivers lives in the stable situation of stress. Caregivers, who where seemed to be emotionally stable, clarify their condition as having energy, troubles, and felt happy, employable. We marked out reasons of insufficient teachers' mental health:

Economical - Educational Problems low educational level, and that's why living wedge, as well; lack of perfection possibilities, because refresh courses are fee - paying, etc.

Personal problems: insufficient motivation, lack of self - confidence; unofficial age limit.

Social problems: quality of public health system, social guaranties, etc.

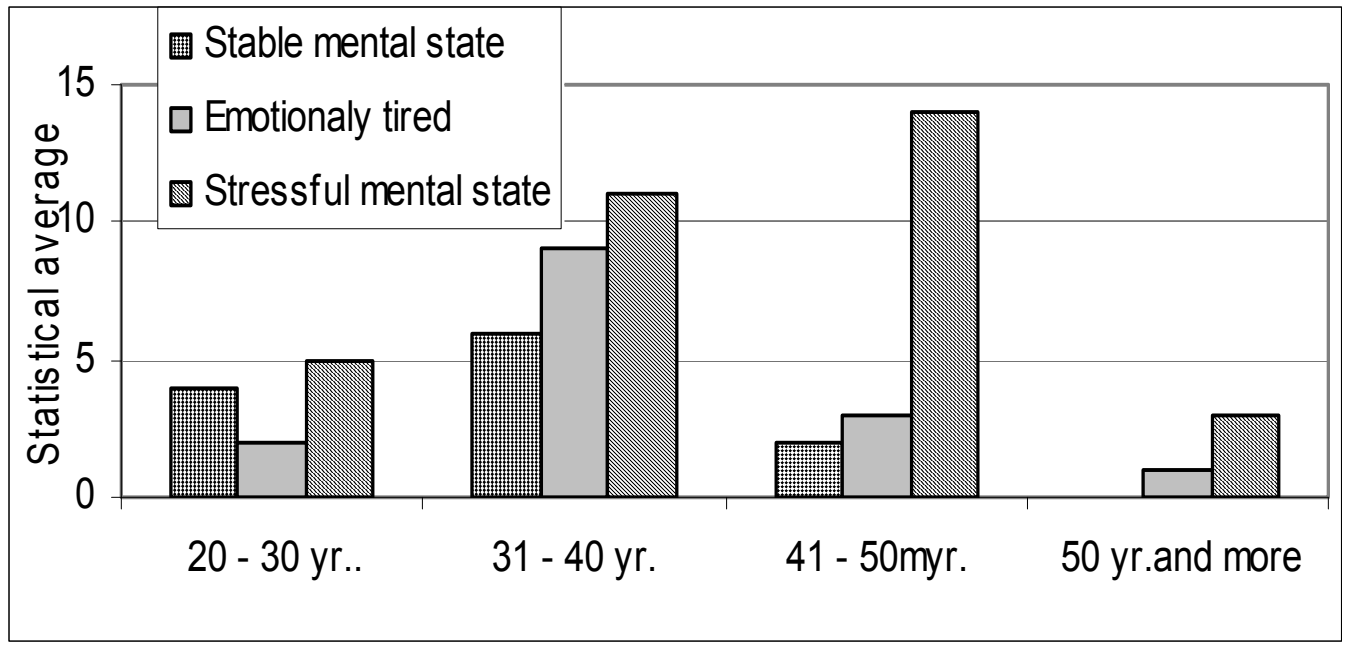

Figure 5 Mental health of infant home teachers 
Social attitudes of pedagogues and its gradually alternation reflects on processes of emotional maturation of school infants. For the children who are brought up in Infant home caregiver is a guarantor of the sense of security that facilitates environmental cognition, and sensor integration - basis of early developmental conditions. Emotional development in early age corresponds with successful social interactions.

Observation data of emotional status of infants and its analysis revealed that emotional reactions and emotional state of infants who are brought up in infant home is not so diverse as it is defined in the Izard (2000) classification. Spitz (2001), Berns R.M. (2008) describes emotional development of infants who are out of family as poor, monotonous, with displaced relationships with adults. In the early age for the wards of infant home instinctive emotional reactions are more common and only later they distinguish with different modality.

There are a lot of people who infants have to contact every day so, the quality and quantity of contacts differ, but emotional development is displaced, because child has no opportunity to attach to one person, his need of safety is not satisfied. In the infant's development in care institution significant periods of dyad, reciprocity are missing.

Table 1

Emotional reactions according gender

\begin{tabular}{|c|c|c|c|c|}
\hline \multirow{2}{*}{ Emotions and emotional status } & \multicolumn{4}{|c|}{ After experiment } \\
\cline { 2 - 5 } & \multicolumn{2}{|c|}{ Boys N-18 } & \multicolumn{2}{c|}{ Girls N-16 } \\
\cline { 2 - 5 } & $\sum$ & $\mathrm{X}$ & $\sum$ & $\mathrm{X}$ \\
\hline Joy & 792 & 18,14 & 561 & 12,21 \\
Interest & $851^{* *}$ & 19,10 & $721^{*}$ & 21,38 \\
Sadness & 709 & 28,23 & 627 & 30,48 \\
Anger & 55 & 4,49 & 32 & 2,89 \\
Anxiety & $122^{*}$ & 6,23 & $110^{* *}$ & 6,13 \\
Homeostatic & 709 & 12,38 & 530 & 11,26 \\
status & & & & \\
\hline
\end{tabular}

* - level of significance $\mathrm{p}<0,05 ; * *$ - level of significance $\mathrm{p}=0,00$

Boys were more joyful than girls. We say that, decreasing of joy emotion is positive process, because according to the theoretical issue of emotional differentiation, emotional reactions of joy transfer to the emotional reactions of interest (Table 1).

Emotion of anxiety among gender groups took place in the analysis of research data, as well. Boys demonstrated more emotional reactions of anxiety according to the emotion of sadness of teacher's. Anxiety was demonstrated in behavior of both - girls and boys.

Emotional reactions of anxious among gender groups reflect insufficiency of emotionally close direct contacts with adults, sense of safety, and quality of 
attachment. Significantly expressed anxiety that was demonstrated can be assessed as typical regularity of psychical development of infants in care institutions. It's obvious, that basic emotional needs can't be developed: they can be satisfied or not.

During the whole process of observation, homeostatic state among girls and boys can be assessed as one of the most stable emotional phenomenon. Why? We suppose, that passive behavior, low motivation for activity might be explained in two ways. First, institutional environment and calm emotional relationships stimulate child's dissociation and recoil from surrounding reality; second, homeostatic state in early infancy might be assessed as non-activated expression on anxiousness.

In general, we found out that negative emotions began to increase together with the child's age and emotional state of teachers. The most critical period is 16-18 months. We can do premise, that this period of age might be defined as the period of manifestation of the first signs of psychical deprivation. Prevalence of negative emotions at this age correlates with psychological stage (group of personal problems) of caregivers.

There are some particularities of infant's emotional reactions according to the gender and psychological health of caregivers. Boys are more emotionally sensitive, they distinguishes by the liability of their emotions. Girls are more to be emotional stable and more "open" to the environmental changes and less sensitive to the particularities of psychological stage of caregivers (economical educational group of reasons).

\section{Conclusions}

We can talk about the tendencies, which became evident in our research:

1. Satisfaction of the basic psychical needs of early age children is the essential condition of educational process and mental health of teachers, as well. Pedagogue in Infant home acts as a creator of the stimulating environment for child's space of development. The number of children and caregivers that we observed is too small to make conclusions about relationship between children's emotional stage and psychological condition of caregivers.

2. Some system or kind of psychological help for pedagogues, who chanced to live and work in the period of changes of the whole socioeconomic structures in the post-communist period, must be organized, because due to various reasons, the most of the caregivers feel them selves psychologically depressed.

3. The analysis of expression of emotional status of infants let us draw a conclusion, that optimal psychological health of caregivers impresses 
emotional condition of deprived infants. The boys are more influenced by psychological condition of caregivers then girls.

\section{Summary}

An article reveals presumptive relationships of mental health of special educators and emotional stage of infants. In this context mental health of teachers (reasons and signs of it) and emotional reactions of infants is discussed. In specific educational environment mental health of teachers is an important factor of successful pedagogical process and infant development, as well. Pedagogue in Infant home acts as a creator of the stimulating environment for child's space of development. The analysis of expression of emotional status of infants let us draw a conclusion, that optimal psychological health of caregivers impresses emotional condition of deprived infants. In general, it was found out that negative emotions began to increase together with the child's age and emotional state of teachers. The most critical period is 16-18 months. We can do premise, that this period of age might be defined as the period of manifestation of the first signs of psychical deprivation. Prevalence of negative emotions at this age correlates with psychological stage (group of personal problems) of caregivers.

There are some particularities of infant's emotional reactions according to the gender and psychological health of caregivers. The boys are more influenced by psychological condition of caregivers then girls and emotionally more sensitive. Girls are more to be emotional stable and more "open" to the environmental changes and less sensitive to the particularities of psychological stage of caregivers (economical - educational group of reasons).

\section{Bibliography}

1. Aramavičiūtè, V. (2006). Jaunuolių dvasingumo šiuolaikinès kaitos tendencijos. Acta paedagogica Vilnensia, (17) p. 45-56.

2. Berns, R.M. (2008). Vaiko socializacija: šeima, mokykla, visuomene. Poligrafija ir informatika. Vilnius

3. Bitinas, B. (2004). Hodegetika. Auklejjimo teorija ir technologija. Kronta. Vilnius

4. Juodaitytè, A., Rūdyte, K. (2009). Diskursas kaip socialinių- edukacinių reiškinių kontekstualaus supratimo metodologine prieiga. Mokytoju ugdymas. Nr. 12 (1), 27-43. Šiaulių universiteto leidykla, p. $27-43$.

5. Kaffemanas, R. (2000). Globos namų ir Specialiujų mokyklų auklètinių elgesio problemos. Specialusis ugdymas III,70-77. Šaulių universiteto leidykla.

6. LEMON (LEarning Materials On Nursing): a package of learning materials for nurses and midwives, feldschers and others performing nursing and midwifery tasks. WHO, 1996. Copenhagen, WHO Regional Office for Europe (document EUR/ICP/DLVR 02/96/1).ns R.M. (2008)

7. Ruškus, J. (2000). Socialinis - psichologinis specialiojo pedagogo portretas nuostatu aspektu. Specialusis ugdymas III, 87-97. Šaulių universiteto leidykla.

8. Ruškus, J., Gerulaitis, D. (2010). Parental Involvement in the Special Needs Education through the Construction of an Individual Plan: A Lithuanian Experience. Illinois child Welfare. Volume $5 \cdot$ Number 1 p.15-32. 
9. Selingman, M. E. P., Walker, E. F., Rosenhan, S. L. (2001). Abnormal Psychology (4th ed.). New York, W.W. Norton Company.

10. Vasiliauskas, R. (2005). Ugdymas ir vertybès: Vertybių ugdymo teoriniai ir praktiniai aspektai. Acta paedagogica Vilnensia. (14) p. 8 - 17

11. Žukauskienè, R. (2012). Raidos psichologija: integruotas požiūris. Margi raštai. Vilnius.

12. Изард, К. (2000). Психология эмоций. Санкт-Петербург: Питер.

13. Шпиц, Р. (2001). Психоанализ раннего детского возраста. Москва: Университетская книга.

\begin{tabular}{|c|c|}
\hline Ph.D. Adolfas Juodraitis & $\begin{array}{l}\text { Department of Social Education and } \\
\text { Psychology, Faculty of Social } \\
\text { Welfare and Disability Studies } \\
\text { Šiauliai University, Lithuania. } \\
\text { E-mail: sppkatedra@cr.su.lt } \\
\text { Tel: +37041595732 }\end{array}$ \\
\hline $\begin{array}{l}\text { Prof.dr. Liuda } \\
\text { Radzevičienė }\end{array}$ & 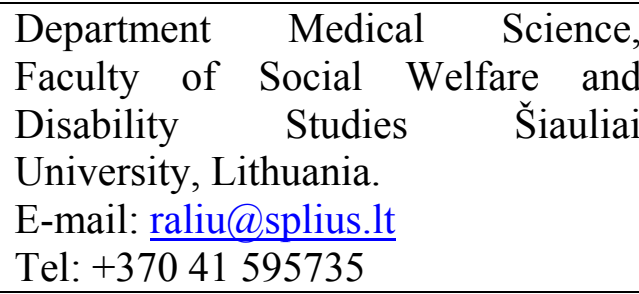 \\
\hline Prof. dr. Diana Strakšienė & $\begin{array}{l}\text { Department of Music Pedagogy, } \\
\text { Faculty of Arts, Šiauliai University, } \\
\text { Lithuania. } \\
\text { E-mail: diana.straksiene@gmail.com } \\
\text { Tel: +370 } 41595868\end{array}$ \\
\hline
\end{tabular}

